真正粘菌における新規ミトコンドリアヒストン様タンパク質Glomの解析

佐々木 成江

お茶の水女子大学大学院 人間文化研究科 遺伝カウンセリングコース

（†112-0012 東京都文京区大塚 2-1-1)

\title{
Identification and Characterization of a novel mitochondrial histone-like protein in Physarum polycephalum
}

\author{
Narie Sasaki \\ Genetic Counseling Program, Graduate School of Humanities and Science, \\ Ochanomizu University \\ (2-1-1 Otsuka, Bunkyo-ku, Tokyo 112-8610, Japan)
}

要旨 : 生体内においてミトコンドリアDNAはタンパク質によって高度に折りたたまれたミトコンド リア核様体（ミトコンドリア核）で存在する。我々は、非常に凝縮した大型ミトコンドリア核様体を 持つ生物の一つである真正粘菌Physarum polycephalumから、新規ミトコンドリアヒストン様タンパク 質Glomを同定した。Glomは、N末端半分にポリプロリンを含むリジンに富む領域を持ち、C末端半 分にHMG boxを持つ塩基性タンパク質であった。Glomは、ミトコンドリアDNA全体に結合し、 DNAの凝縮を促進するが、その凝縮にはリジンリッチ領域が重要であった。また、Glomによる激し いDNAの凝縮は複製や転写などの機能発現を全く阻害せず、その機能発現にはポリプロリンが重要 であった。さらに、Glomは大腸菌のヒストン様タンパク質であるHUの機能を相補し、その機能相 補にはHMGボックス領域が重要であった。

Summary : Mitochondrial DNA (mtDNA) is packed into highly organized structures called mitochondrial nucleoids (mt-nucleoids). We identified and characterized a new mitochondrial histone-like protein, termed Glom (a protein inducing agglomeration of mitochondrial chromosome), from highly condensed mt-nucleoids of the true slime mold, Physarum polycephalum. This protein has a lysine-rich region with proline-rich domain in the N-terminal half and two HMG boxes in C-terminal half. Glom induced intensive DNA condensation without suppressing replication and transcription. The lysine-rich region was sufficient for the mtDNA condensation and the proline-rich domain was essential to keep those genetic activities. The expression of Glom also complemented the E. coli mutant lacking the bacterial histone-like protein $\mathrm{HU}$ and the HMG-boxes region of Glom was important for the complementation.

Key Words: : Glom, mitochondrial nucleoid, histone-like protein, HMG-box 


\section{1.はじめに}

ミトコンドリアは独自のDNAを含有し、細胞核の遺伝情報にかなりの部分を依存しつつも半自立的 に増殖する細胞小器官である。ミトコンドリア内でDNAは、様々なタンパク質とともに高次の複合体 を形成し、ミトコンドリア核様体（ミトコンドリア核）として存在する（Kuroiwa，1982）。高等真 核生物のミトコンドリア核様体には、約 $17 \mathrm{kbp}$ DNAが2-5分子しか含まれておらず、DAPI巣光 顕微鏡法では多くの場合小さなスポットにしか観察されない。また、電子顕微鏡では、大部分のミト コンドリアDNAは周辺の電子密度が高い領域に埋もれてしまい、ごく一部のみが電子密度の低い白く 抜けた部分に繊維状に観察されるのみであり、in vivoの状態を反映した詳細な構造解析は不可能であ る。一方、真正粘菌は、非常に発達した棒状のミトコンドリア核様体を持つ（図 $1 \mathrm{~A}$ )。一つのミトコ ンドリア核様体には、63 kbpの環状ミトコンドリアDNAが40-80コピー含まれている (Kuroiwa and Kuroiwa, 1980, Takano et al., 2001)。電子顕微鏡においても、電子密度の高い構造としてミ トコンドリア核様体をはっきり観察することができ（図1B)、形態・構造学的な解析に非常に優れた 材料といえる。

真正粘菌のミトコンドリア核様体内のDNAは非常に凝縮しており、そのパッキング率は細胞核のへ テロクロマチンに相当する。一般に、ヘテロクロマチンのようなDNAが強く圧縮された状態は不活発 な状態であり、DNA合成や遺伝子発現などの活性は低いと考えられる。しかし、ミトコンドリア核様 体は活発にDNA合成やRNA合成を行っている。このことは、ミトコンドリア核様体内でDNAは、ミ トコンドリアゲノムの機能発現を妨げることなく、効率よく圧縮できる方法で組織化されていると考 えられる。このようなミトコンドリア核様体の高次構造は、DNAとタンパク質の相互作用により保た れている。実際、真正粘菌から単離したミトコンドリア核様体を電子顕微鏡で観察すると、ヌクレオ ソーム様のビーズ状構造を観察することができるが（図 1 C)、それをプロテアーゼ処理すると、多数 のミトコンドリアDNA分子が裸出してくる (図 $1 \mathrm{D}$ )。細胞核では、主要な構造タンパク質として塩 基性タンパク質であるヒストンが挙げられる。ヒストンはDNAと非特異的に結合してヌクレオソーム を形成する。ヌクレオソームは、ヒストン八量体 $(\mathrm{H} 2 \mathrm{~A} \cdot \mathrm{H} 2 \mathrm{~B} \cdot \mathrm{H} 3 \cdot \mathrm{H} 4)$ の周りにDNA (147bp) が約 2 回巻きついた構造体であり、DNAの高次構造の基本単位である。現在のところ、ミトコンドリ アDNAがこのようなヌクレオソーム構造をとるか否かは不明である。

これまでに、ミトコンドリア核様体にもヒストン様タンパク質があることが予想され、いくつかの 生物で探索されてきた。酵母（Saccharomyces cervisiae）では、約20 kDaの塩基性夕ンパク質である Abf2pが同定されている (Caron et al., 1979, Diffley and Stillman, 1991)。Abf2pは、ミトコンド リア核様体タンパク質の主要構成成分の一つであり、ミトコンドリアDNAのパッケージングに関与す る。Abf2pは、HMGタンパク質のDNA結合モチーフであるHMGボックスを二つ含む。HMGタンパ ク質は、ヒストンに続く主要な核タンパク質であり、DNAとの結合はヒストンと比較して弱
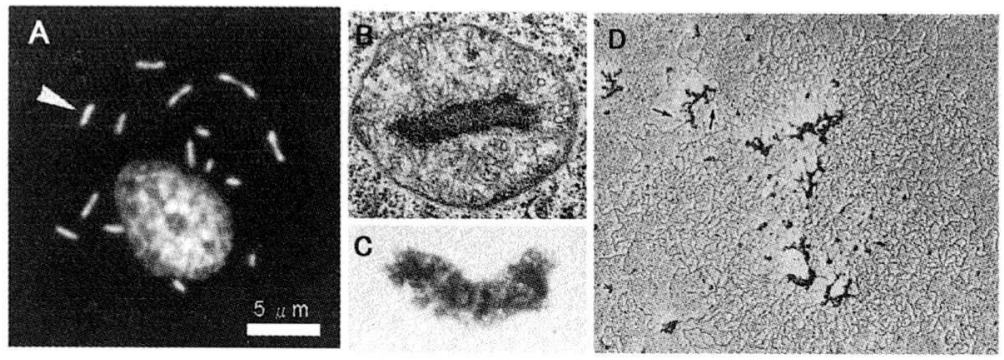

図 1. 真正粘菌のミトコンドリア核様体

A：DAPI染色による蛍光顕微鏡像

B: ミトコンドリアの電子顕微鏡像(TEM)

C: 単離ミトコンドリア核様体のネガティブ 染色による電子顕微鏡像

D: プロテアーゼ処理後のミトコンドリア核 梯体の電子顕微鏡像 
く、可逆的である。このようなHMGボックスを持つタンパク質は、ミトコンドリアの転写因子 (TFAM) としてヒトやXenopusをはじめ様々な高等動物でも見つかっている (Parisi and Clayton, 1991, Antoshechkin and Bogenhagen, 1995)。また、ヒトやXenopusでは、TFAMはミトコンドリア内に 大量に存在することから、転写因子としてだけではなく、ミトコンドリアDNAのパッケージングにも 重要な㗢きをしていると考えられている。一方、トリパハソーマからは、リジン含量が高く、ヒスト ンH1 と相同性が高い20 $\mathrm{kDa}$ 以下の塩基性タンパク質（p16・p $17 \cdot \mathrm{p} 18 \cdot \mathrm{p} 19 \cdot \mathrm{p} 21$ ）が同定され ている(Xu et al., 1996, Hines and Ray, 1998)。トリパノソーマのミトコンドリア核様体（キネトプ ラストDNAディスク）は、電子密度の高い円盤状の構造をしており、その中には約 5,000 分子の小環 状DNAと20-30分子の大環状DNAが含まれている。精製したタンパク質をそれらのキネトプラスト DNAに添加すると、DNAの凝縮が見られることから、それらのタンパク質は核様体の高次構造に重 要であると考えられている。これまでに、これらの 2 つのタプのミトコンドリアヒストン様タンパ ク質が同定されているが、筆者らは真正粘菌から新規ミトコンドリアヒストン様タンパク質である Glomを同定し、いくつかの新しい知見を得てきた（Sasaki et al., 2003)。このミニレビューでは、そ の内容を中心に概説する。

\section{2. 真正粘菌のミトコンドリアヒストン様タンパク質Glomの同定}

真正粘菌のミトコンドリア核様体の高次構造 に関与するタンパク質を同定するために、単離 したミトコンドリア核様体を様々な濃度の $\mathrm{NaCl}$ で処理し、核様体の高次構造が解体される際に 遊離してくるタンパク質を調べた。図 $2 \mathrm{~A} て ゙$ 示 すように、ミトコンドリア核様体の高次構造は、 $0.2 \mathrm{M}$ の NaCl処理で解体されはじめ、0.3 M以 上では完全に解体されたことから、高次構造に 関与するタンパク質は、0.2-0.3Mで遊離してく ると推定された。また、 $\mathrm{NaCl}$ 処理でミトコンド リア核様体から遊離してくるタンパク質をSDSPAGEで調べたところ、高次構造の解体が観察 されはじめる0.2-0.3M 付近で、ミトコンドリア 核様体の主要構成タンパク質である $41 \mathrm{kDa}$ タン パク質が遊離することがわかった（図 2 B)。

そこで、ミトコンドリア核様体から $41 \mathrm{kDa}$ ンパク質を精製し、DNA結合能をゲルシフト法 により調べた。精製した $41 \mathrm{kDa}$ タンパク質と X $b a$ I で切断したミトコンドリアDNA断片を同時 にインキュベートし、アガロースゲル電気泳動 をおこなったところ、41 kDaタンパク質はすべ てのDNA断片に結合した。このことは、 $41 \mathrm{kDa}$ タンパク質は非特異的にDNAに結合す ることを示している。また、他の断片と比較し

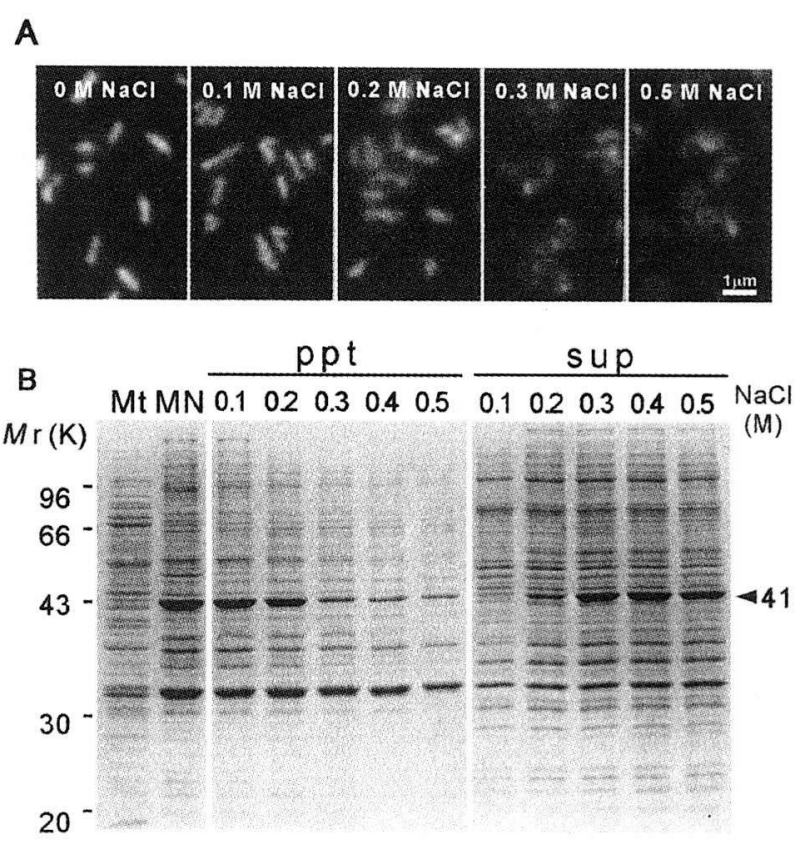

図 2. NaCI処理によるミトコンドリア核様体の解体 $\mathrm{A}$ ：単離ミトコンドリア核様体を様々な $\mathrm{NaCl}$ 濃度で処理し、 DAPI染色し、巣光顕微鏡で観察した。

B: NaCl処理した単離ミトコンドリア核様体を遠心し、 沈殿（ppt）と上清（sup）をそれぞれSDS - PEGEした。 Mt はミトコンドリア、MN はミトコンドリア核様体を 示す。 

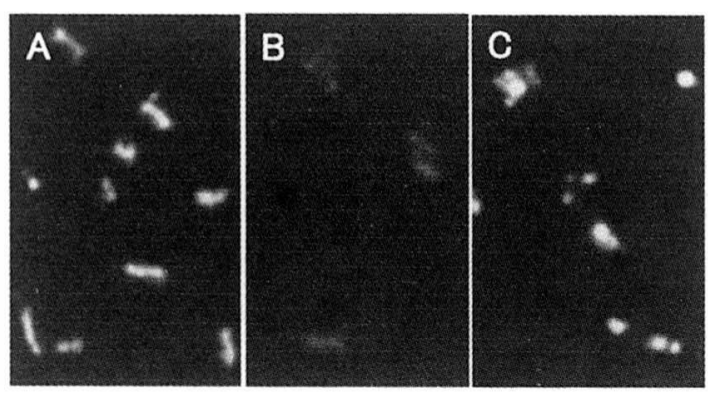

図 3．精製した $41 \mathrm{kDa}$ タンパク質を用いたミトコ ンドリア核椂体の解体一再構成

$0.3 \mathrm{MNaCl}$ 処理により解体したミトコンドリア核様体を 透析し、再構成したものを DAPI 染色により観察した。 $\mathrm{A}$ ：透析のみ、 $\mathrm{B}$ ：遠心後に上清を除去して透析、C：上 清の除去後に $41 \mathrm{kDa}$ タンパク質を添加して透析
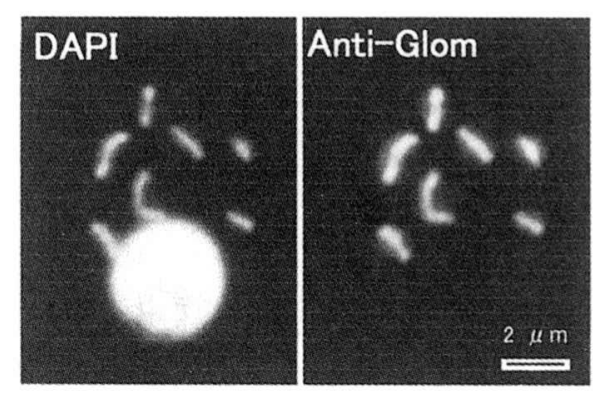

図 4. 抗 Glom 抗体を用いた細胞染色 抗 Glom 抗体により、ミトコンドリア核様体が 特異的に、かつ一様に染色された。

て18.4kbpのDNA断片に対する親和性が高く、このような親和性の差は、ラムダファージDNA断 片を用いた際には見られなかったことから、41kDaタンパク質はミトコンドリアDNAの一部の領域 に対しては選択的に結合しやすい性質をもつといえる。ABF2やTFAMにおいても、DNAに対して 非特異的に結合するが、ミトコンドリアDNAの複製や転写開始点付近と親和性が高いことが報告さ れている (Fisher et al., 1987, Diffley and Stillman, 1992)。真正粘菌において、ミトコンドリア DNAの複製や転写開始点はまだ決定されていないが、18.4 kbpの断片にはミトコンドリア膜に結合 する領域が含まれており (Kawano and Kuroiwa, 1985, Kuroiwa et al., 1994)、バクテリアとの 類似性からその領域付近がミトコンドリアDNAの複製や転写開始に関与している可能性は高い (Hoshino et al., 1987, Yung and Kornberg, 1988)。

次に、41 kDaタンパク質がDNAを凝縮させるかどうかを調べるために、ミトコンドリア核様体 の解体一再構成系を用いた解析をおこなった（図 3 )。ミトコンドリア核様体の高次構造の解体一再 構成は、塩濃度を変化させることによって行うことができる。 $0.3 \mathrm{M} \mathrm{NaCl}$ 処理により解体されたミ トコンドリア核様体は、透析により徐々に塩濃度を下げることにより棒状の核様体に再構成される (図 $3 \mathrm{~A}$ )。一方、透析前に、0.3 MNaCl処理で遊離してきたタンパク質を遠心により除去すると再構 成は生じない（図 3 B)。そこで、そこに精製した $41 \mathrm{kDa}$ タンパク質を添加し、透析をおこなうこと で再構成が見られるかどうか調べた。その結果、41kDaタンパク質を添加したものでは、非常に凝 縮した核様体が再構成されることがわかった（図 $3 \mathrm{C}$ )。また、再構成されたミトコンドリア核様体 は棒状ではないことから、棒状構造にはそのほかの因子が関与していることが示唆され、41kDa夕 ンパク質をミトコンドリアゲノムの凝縮（agglomeration）を促進するタンパク質ということで Glomと名づけた。

抗Glom抗体を作成し、細胞染色を行ったところ、Glomはミトコンドリア核様体特異的に局在し ていた（図 4)。また、ミトコンドリア核様体が一様に染色されたことから、Glomはミトコンドリ アDNA全体に結合していることがわかった。実際、ミトコンドリア核様体に含まれるGlom含量か ら計算すると、GlomはミトコンドリアDNAあたり約 $20 \mathrm{bp} に 一$ 分子結合している。これは、ミトコ ンドリアDNA全体をカバーするのに十分な量であり、Glomはヒストン様の構造タンパク質である といえる。 


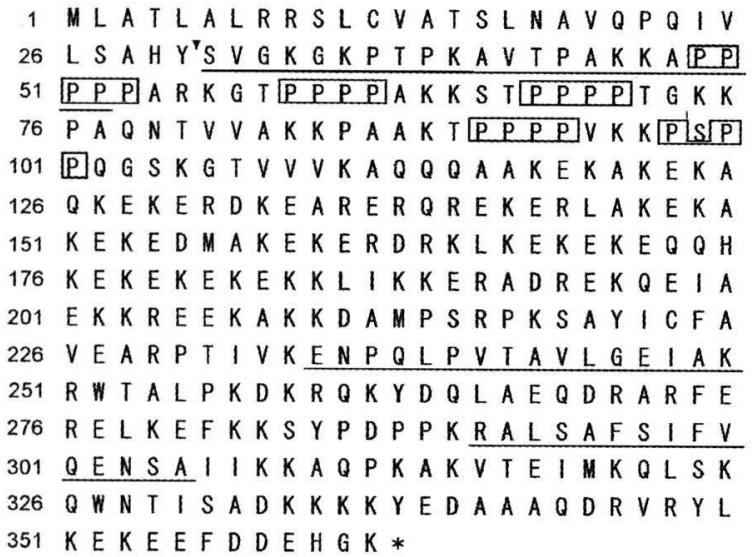

図 5. Glom のアミノ酸配列

アミノ酸シークエンスにより決定された $\mathrm{N}$ - 末端および 2つの内部アミノ酸配列を下線で示す。Glom は、31番 目のセリン（『）から始まる。枠で囲った部分は、N- 末 端側に存在するポリプロリンを示す。

A

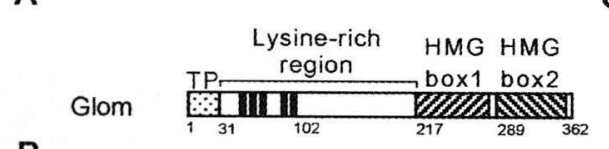

B

rGlom I (31-362) rGlom II (31-216) rGlom III (217-362)

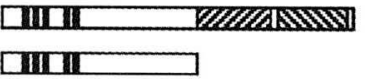
rGlom IV (31-104) ㅁIIIIII rGlom V (102-216) rGlom VI (217-288) rGlom VII (289-362) rGlom VIII (102-362)
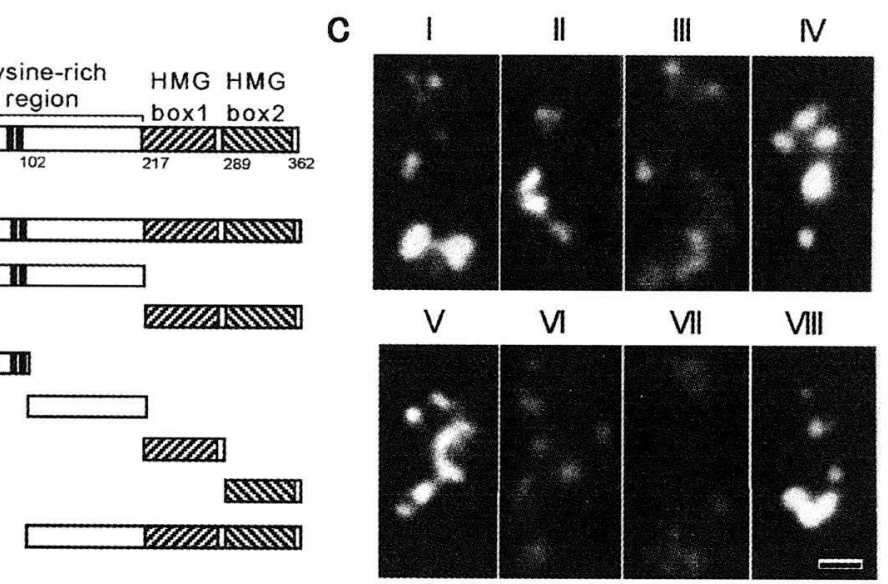

図 6. Glom の機能ドメインの 解析

A: Glomの模式図 TP はミトコンド リアに輸送されるためのターゲテ イングペプチドを示す。

B: Glom の組換えタンパク質のコン ストラクト。

C: 組換えタンパク質を用いたミトコ ンドリア核様体の解体一再構成上 記の番号は、添加したそれぞれの 組換えタンパク質の番号を示す。

\section{Glomの一次構造の決定}

Glom遺伝子を決定するために、精製したGlomを用いてN末端と内部アミノ酸配列をアミノ酸シ ークエンスにより決定し、そこからdegenerated プライマーを作成し、PCRをおこなった。増幅し てきたDNA断片をプローブとしてcDNAライブラリーをスクリーニングしたところ、362アミノ酸 からなるGlom遺伝子の全長が決定された（図 5 )。この遺伝子は、ミトコンドリアゲノム上にコー ドされていないことから (Takano et al., 2001)、核ゲノム上にコードされていると考えられる。ま た、アミノ酸シークエンスにより得られた $\mathrm{N}$-末端のアミノ酸配列は31番目から始まっていることか ら、最初の30アミノ酸はミトコンドリアへ輸送されるためのターゲティングペプチドであると推定 される。

Glomはリジンを多く含み $(21.7 \%)$ 、推定等電点 10.4 の塩基性タンパク質であった。ホモロジー 検索をしたところ、C-末端側半分に二つのHMGボックスがあることがわかつた（図 6 A)。Abf2pや TFAMも同様に二つのHMGボックスを持っているが、ほぼその領域のみからなるタンパク質である。 それらのタンパク質と比較すると、GlomはN-末端側に5箇所の特徵的なポリプロリン (PPPP) を もつリジン含量の高い (26.8\%) 長い配列をもつていた。このリジン含量は、クロマチンの凝縮を 促進するヒストンH1に相当する。トリパハソーマのp16・p $17 \cdot \mathrm{p} 18 \cdot \mathrm{p} 21$ もリジン含量が高く、 ヒストンH1と相同性が高いが（Xu et al., 1996, Hines and Ray, 1998)、HMGボックスを含まな い。よって、Glomはリジンリッチ領域とHMGボックスの両者を含む新しいタイプのミトコンドリ 


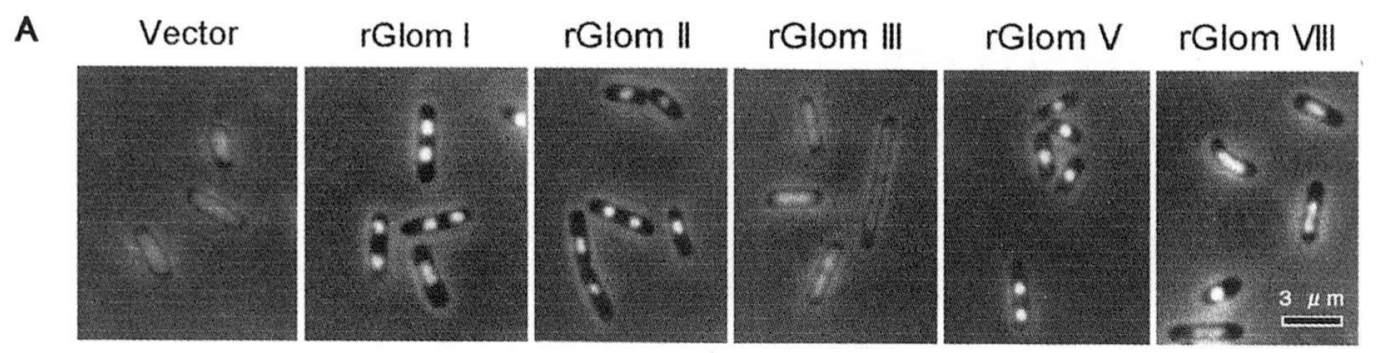

B

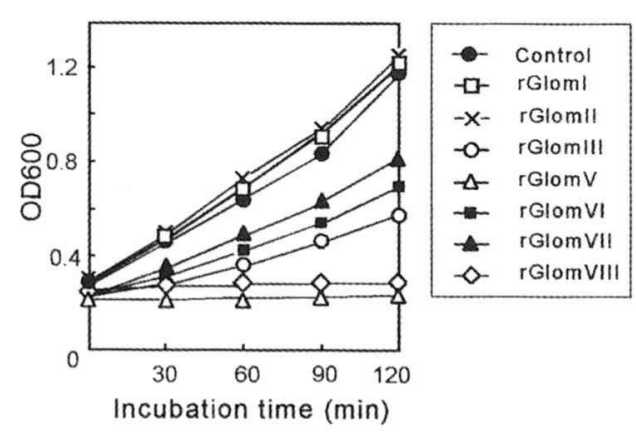

C

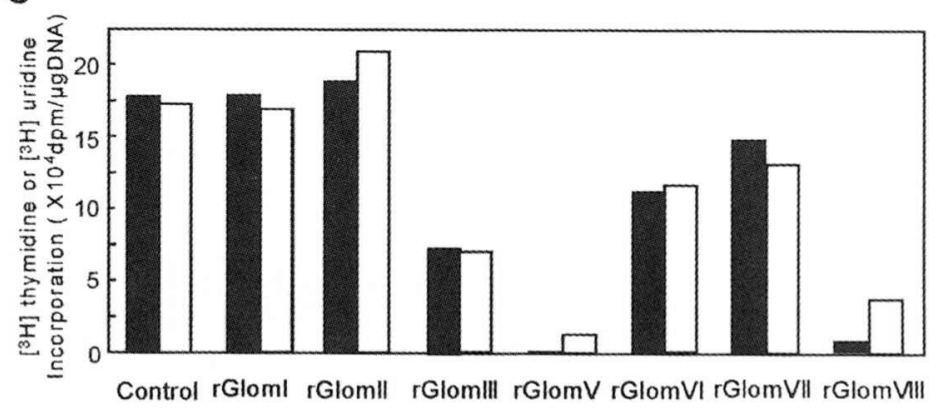

図 7. Glom の組換えタンパク質発現が大腸菌に与える影響

A: それぞれの組換えタンパク質を大腸菌で発現させ、SYTO11によりDNA を生体染色し観察した。B: 大腸菌の細胞增殖を OD600 で測定した。C: 大腸菌の DNA/RNA 合成量を $\left[{ }^{3} \mathrm{H}\right]$ チミジンと $\left[{ }^{3} \mathrm{H}\right]$ ウリジンの DNA への取り込みで測定した。また、 rGlomIV に関しては、発現量が低かったため解析できなかった。

アヒストン様タンパク質であるといえる。

また、Glomの様々な領域を含む組換えタンパク質を大腸菌で作成し（図 6 B)、それぞれの領域の DNA結合能をゲルシフト法により調べたところ、HMGボックス領域だけではなく、リジンリッチ領 域、ポリプロリン領域にもDNA結合能があることがわかった。このことは、GlomはDNAと複数箇所 で結合している可能性を示唆している。また、それぞれの領域のDNA凝縮能を解体一再構成系を用い て調ベたところ、リジンリッチ領域を含む組換えタンパク質 $(\mathrm{rGlom} I \cdot \mathrm{II} ・ \mathrm{IV} ・ \mathrm{~V} ・ \mathrm{VIII})$ はDNA凝 縮能を持つが、HMGボックス領域のみ $($ rGlom III・VI・VII) ではDNA凝縮能を持たないことがわ かった (図 6 C)。

\section{4. 大腸菌を用いたGlomの解析}

大腸菌におけるゲノムDNAのパッケージング率は低く、真正粘菌のミトコンドリア核様体と比較す ると約1/10である。大腸菌でGlomの全長（rGlom I）を発現させると、Glomは大腸菌DNAに結合 し、核様体の激しい凝縮を引き起こした（図 $7 \mathrm{~A}$ )。このような核様体の凝縮は、クラミジアで同定さ れたヒストンH 1 様タンパク質 (Hc 1) を大腸菌で過剩発現した際にも観察されている (Barry et al., 1992)。Hc1は、クラミジア感染初期段階である代謝的に不活性なエレメンタルボディの時期に特異 的に発現するタンパク質である (Hackstadt et al., 1991)。エレメンタルボディ内のクロマチンは非 常に凝縮しており、Hc1はその凝縮に関与していると考えられている。このHc1を大腸菌で発現させ ると、核様体の凝縮とともに大腸菌の増殖阻害、DNA/RNA合成阻害を引き起こすことが報告されて いる (Barry et al., 1993)。しかし、面白いことにGlomを発現させた大腸菌では核様体が非常に凝縮 しているにもかかわらず、大腸菌の増殖（図 7 B)、DNA/RNA合成（図 7 C）には全く影響を 
与えなかつた。このようなGlomの性質は、真正粘菌の強く凝縮したミトコンドリア核様体でDNA の機能発現するために重要な役割を果たしていると考えられる。

では、Glomのどの領域が凝縮したDNAの機能発現に重要なのであろうか? 様々な領域の組換え タンパク質を大腸菌で過剩発現させたところ、解体一再構成系を用いた実験結果と同様にHMGボッ クス領域のみを発現した大腸菌（rGlom III）では核様体の凝縮は起こらず、リジンリッチ領域を含

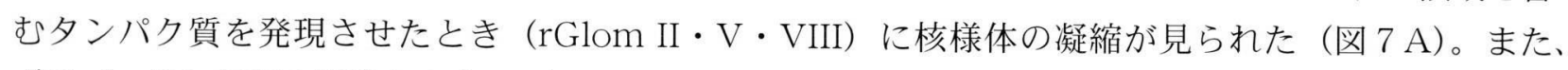
ポリプロリン領域を削除したもの (rGlom・V・VIII) で、核様体の凝縮と同時に著しい増殖阻害（図 $7 \mathrm{~B}$ )、DNA/RNA合成阻害がみられた（図７Ｃ）。これらは、ポリプロリン領域が凝縮したDNAの 機能発現に重要であることを示している。これまでに、プロリンリッチな領域は、真核生物の転写 因子の転写活性ドメインの一つとして知られている (Mermod et al., 1989, Gerster et al., 1990, Tanaka et al., 1994)。特に、転写因子であるCTF/NF1のプロリンリッチ領域は、転写活性装置や ヒストンH3に直接結合することにより転写を活性化することが知られている (Kim and Roeder, 1994, Chiang and Roeder, 1995, Alevizopoulos et al., 1995)。また、一般的にプロリンリッチな 領域はステッキィなアームとして㗢くことが知られており、その結合は迅速かつ可逆的で、タンパ ク質やポリフェノールやDNAなど幅広い物質に結合する (Williamson, 1994)。このようなプロリ ンリッチ領域の柔軟性のある性質が、凝縮したDNAに対するタンパク質の接近を可能とさせ、その 結果として機能発現を促進しているのかもしれない。

\section{5.大腸菌ヒストン様タンパク質HUに対するGlomの機能的相補}

HUは、大腸菌のヒストン様タンパク質として同定されたタンパク質であり、細胞内に大量に存在 し、DNAと非特異的に結合しパッケージングを促進する（Rouviere-Yaniv and Gros, 1975, Rouviere-Yaniv et al., 1979)。また、HUは複製、組換え、染色体の分配など様々な機能に関与し ていることも報告されている。HUは、hupA とhupB遺伝子にコードされる二つのサブユニットからな るへテロ二量体であり、hup $A$ とhupBのどちらかの遺伝子を欠質した変異株は、正常な表現型を示

A

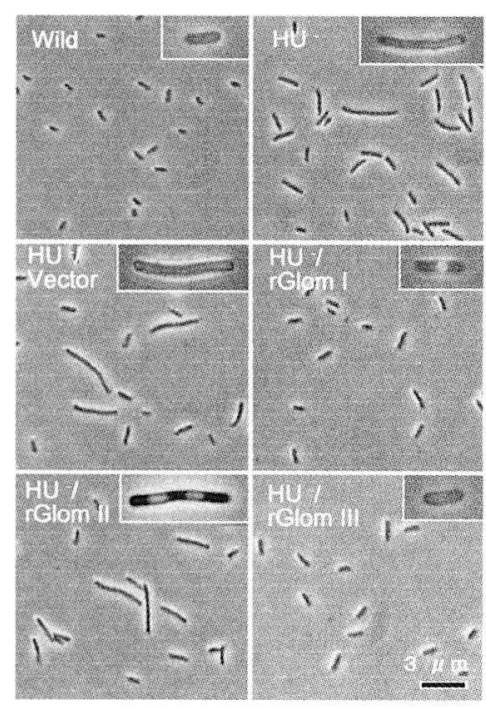

B

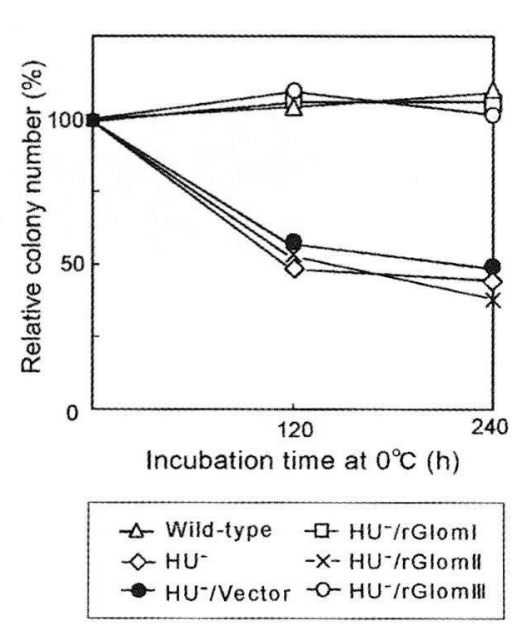

図 8.HU 欠損株を用いた Glom の 相補実験

A: 細胞のフィラメント化に関する解析 HU 欠損株でGlom 組換えタンパク 質を過剩発現し、細胞の形態を観察 した。枠内は、SYTO11によるDNA の生体染色像を示す。

B: 低温感受性に関する解析 HU 欠損株で Glom 組換えタンパク 質を過剩発現したものを、 $0{ }^{\circ} \mathrm{Cでイン}$ キュベートした後に、プレートにま き、コロニー数を測定した。野生型 を100\%としてその他の值を示し た。 
すが、両方の遺伝子を欠質した変異株では、フィラメント状の形態や低温感受性を示す (Wada et al., 1988)。これまでに、HU欠損株でのAbf $2 \mathrm{p} p 16 / \mathrm{p} 17 / \mathrm{p} 18$ 発現は、変異株でのフィラメント状 への形態変化を回復することから、HUとアミノ酸配列上の類似性は見られないが、機能的には類似 していると考えられている (Megraw and Chae, 1993, Xu et al., 1996)。そこで、GlomもHUの機 能を相補できるかどうか調べてみた。その結果、Glomの全長（rGlom I）はHU欠損株のフィラメ ント状への形態変化(図8A)や低温感受性を回復させることがわかった（図8B)。また、HUの機能相 補にはリジンリッチ領域（rGlom II）ではなくHMGボックス領域（rGlom III）が重要であった。

\section{6. 終わりに}

ミトコンドリアや色素体の祖先は、原核生物が内部共生したものであると考えられている。大腸 菌で同定されたHUは、多くの細菌で同定されており、ミトコンドリアの祖先に最も近い生物の一つ であるリケッチアからも同定されている（Anderson et al., 1998）。また、HUのホモログは、いく つかの原始的な紅藻類の色素体からも見つかっており、色素体DNAのパッケージングに重要な働き をしていることがわかっている（Kobayashi et al., 2002）。しかし、ミトコンドリアからはまだ見 つかっていない。Glomを含めてこれまでに同定されたミトコンドリアヒストン様タンパク質の相補 実験の結果を考えると、HUは進化上かなり初期段階で機能的に類似した細胞核由来のHMGボック スタンパク質やヒストンH1に置換されたと推定できる。また、生物種によって様々なタイプのミト コンドリアDNAパッケージングタンパク質が同定されていることから、ミトコンドリアヒストン様 タンパク質は進化の過程で変化しているといえる。では、それらのタンパク質の進化は何を意味す るのであろうか?それぞれの生物のミトコンドリア核様体の高次構造を比較してみると、真正粘菌 やトリパハゾーマなどリジン含量の高いタンパク質によって構成されるミトコンドリア核様体の電 子密度は高く、酵母や高等生物などのHMBボックスタンパク質によって構成されるミトコンドリア 核様体の電子密度は低い。これは、HMGボックス領域よりもリジンリッチ領域のほうがDNAをパ ッケージングする能力が高いというパッケージングの差を反映していると考えられる。そのような 高いパッケージング能は、真正粘菌やトリパノソーマに見られる大型のミトコンドリア核様体の維 持に重要なのかもしれない。また、Glomはリジンリッチ領域とHMGボックス領域の両者を持って いることから、ミトコンドリアヒストン様タンパク質の進化の過渡的な段階にあると考えられる。

\section{謝辞}

本総説に関連する研究を行うにあたり立教大学の黒岩常祥先生および黒岩晴子先生、お茶の水女 子大学の室伏きみ子先生にご指導・ご助言をいただいたことに深く感謝いたします。

\section{引用文献}

Alevizopoulos, A., Dusserre Y., Tsai-Pflugfelder, M., von der Weid, T., Wahli, W. and Mermod, N. (1995) A proline-rich TGF-beta-responsive transcriptional activator interacts with histone $\mathrm{H} 3$. Genes Dev. 15: 3051-3066. 
Andersson, S.G., Zomorodipour, A., Andersson, J.O., Sicheritz-Ponten, T, Alsmark, U.C., Podowski, R.M., Naslund, A.K., Eriksson, A.S., Winkler, H.H. and Kurland, C.G. (1998) The genome sequence of Rickettsia prowazekii and the origin of mitochondria. Nature 396: 133-140.

Antoshechkin I. and Bogenhagen, D.F. (1995) Distinct roles for two purified factors in transcription of Xenopus mitochondrial DNA. Mol. Cell. Biol. 15: 7032-7042.

Barry, III, C.E., Hayes, S.F. and Hackstadt, T. (1992) Nucleoid condensation in Escherichia coli that express a chlamydial histone homolog. Science 256: 377-379.

Barry, III,C.E., Brickman, T.J. and Hackstadt, T. (1993) Hc1-mediated effects on DNA structure: a potential regulator of chlamydial development. Mol. Microbiol. 9: 273-283.

Caron, F., Jacq, C. and Rouvière-Yaniv, J. (1979) Characterization of a histone-like proteinextracted from yeast mitochondria. Proc. Natl. Acad. Sci. USA. 76: 4265-4269.

Chiang, C. M. and Roeder, R.G. (1995) Cloning of an intrinsic human TFIID subunit that interacts with multiple transcriptional activators. Science 267: 531-536.

Diffley, J.F.X. and Stillman, B. (1991). A close relative of the nuclear, chromosomal high-mobility group protein HMG1 in yeast mitochondria. Proc. Natl. Acad. Sci. USA. 88: 7864-7868.

Fisher, R.P., Topper, J.N. and Clayton, D.A. (1987) Promoter selection in human mitochondria involves binding of a transcription factor to orientation-independent upstream regulatory elements. Cell 50: 247-258.

Gerster, T., Balmaceda, C.-G. and Roeder, R.G. (1990) The cell type-specific octamer transcription factor OTF-2 has two domains required for the activation of transcription. EMBO J. 9: 1635-1643.

Hackstadt, T., Baehr, W. and Ying, Y. (1991) Chlamydia trachomatis developmentally regulated protein is homologous to eukaryotic histone H1. Proc. Natl. Acad. Sci. USA. 88: 39373941.

Hoshino, T., McKenzie, T., Schmidt, S., Tanaka, T., Sueoka, N. (1987) Nucleotide sequence of Bacillus subtilis dnaB: a gene essential for DNA replication initiation and membrane attachment. Proc. Natl. Acad. Sci. USA. 84: 653-657

Hines J.C. and Ray, D.S. (1998) The Crithidia fasciculata KAP1 gene encodes a highly basic protein associated with kinetoplast DNA. Mol. Biol. Parasitol. 94: 41-52.

Kawano, S., and Kuroiwa, T, (1985) Isolation and characterization of a membrane-DNA complex in the mitochondrial of Physarum polycephalum. Exp.Cell Res.16: 460-472

Kim, T.K. and Roeder R.G. (1994) Proline-rich activator CTF1 targets the TFIIB assembly step during transcriptional activation. Proc. Natl. Acad. Sci. USA. 91: 4170-4174.

Kobayashi, T., Takahara, M., Miyagishima, S., Kuroiwa, H., Sasaki, N., Ohta, N., Mastuzaki, M. and Kuroiwa, T. (2002) Detection and localization of chloroplast-encoded HU-like protein that organizes chloroplast nucleoids. Plant Cell 14: 1579-1589.

Kuroiwa, T. and Kuroiwa, H. (1980) Inhibition of Physarum mitochondrial division by cytochalasin B. Experientia 36: 193-194. 
Kuroiwa, T. (1982) Mitochondrial nuclei. Int. Rev. Cytl. 75: 1-59.

Kuroiwa, T., Ohta, T., Kuroiwa, H. and Kawano, S. (1994) Molecular and cellular mechanisms of mitochondrial nuclear division and mitochondriokinesis. Microsc. Res. Tech. 27: 220-232.

Megraw, T.L. and Chae, C.B. (1993) Functional complementarity between the HMG1-like yeast mitochondrial histone HM and the bacterial histone-like protein HU. J. Biol. Chem. 268: 12758-12763.

Mermod, N., O'Neill, E.A., Kelly T.J. and Tjian, R. (1989) The proline-rich transcriptional activator of $\mathrm{CTF} / \mathrm{NF}-1$ is distinct from the replication and DNA binding domain. Cell 58: 741-753.

Parisi, M.A. and Clayton, D.A. (1991) Similarity of human mitochondrial transcription factor 1 to high mobility group proteins. Science 252: 965-969.

Rouvière-Yaniv, J. and Gros, F. (1975) Characterization of a novel low-molecular-weight DNA-binding protein from Escherichia coli. Proc. Natl. Acad. Sci. USA. 72: 3428-3432.

Rouvière-Yaniv, J., Yaniv, M., and Germond, J.E. (1979). E. coli DNA binding protein HU forms nucleosome like structure with circular double-stranded DNA. Cell 17: 265-274.

Sasaki, N., Kuroiwa, H., Nishitani, C., Takano, H., Higashiyama, T., Kobayashi, T., Shirai, Y., Sakai, A., Kawano, S., Murakami-Murofushi, K., and Kuroiwa, T.(2003) Glom is a novel mitochondrial DNA packaging protein in Physarum polycephalum and causes intense chromatin condensation without suppressing DNA functions. Mol. Biol. Cell 14:4758-4769.

Takano, H., Abe, T., Sakurai, R, Moriyama, Y., Miyazawa, Y., Nozaki, H., Kawano, S., Sasaki, N. and Kuroiwa, T. (2001) The complete DNA sequence of the mitochondrial genome of Physarum polycephalum. Mol. Gen. Genet. 264: 539-545.

Tanaka, M., Clouston, W.M. and Herr W. (1994) The Oct-2 glutamine-rich and proline-rich activation domains can synergize with each other or duplicates of themselves to activate transcription. Mol. Cell. Biol. 14: 6046-6055.

Xu, C.W., Hines, J.C., Engel, M.L., Russell, D.G. and Ray, D.S. (1996) Nucleus-encoded histone H1-like proteins are associated with kinetoplast DNA in the Trypanosomatid Crithidia fasciculata. Mol. Cell. Biol. 16: 564-576..

Wada, M., Kano, Y., Ogawa, T., Okazaki, T. and Imamoto F. (1988) Construction and characterization of the deletion mutant of hupA and hupB genes in Escherichia coli. J.

Mol. Biol. 204: 581-91.

Yung, B.Y. and Kornberg, A. (1988) Membrane attachment activates dnaA protein, the initiation protein of chromosome replication in Escherichia coli. Proc. Natul. Acad. Sci. USA 85: $7202-7205$ 